${ }^{1}$ В.П. Харченко, д.т.н., проф.

${ }^{2}$ C.I. Рудас, к.Т.н. НАУ, старш. викл.

\title{
ЛЮДИНА-ОПЕРАТОР У МАЙБУТНІЙ СИСТЕМІ ОБСЛУГОВУВАННЯ ПОВІТРЯНОГО РУХУ
}

\author{
Національний авіаційний університет \\ ${ }^{1}$ E-mail: kharch@nau.edu.ua \\ ${ }^{2}$ E-mail: rudassi@mail.ru
}

Розглянуто взаємний вплив оператора аеронавігаційної системи (авіадиспетчера) та технічної складової полієргатичної системи обслуговування повітряного руху на надійність обслуговування повітряного руху з урахуванням роботи одного оператора в складі команди.

Ключові слова: надійність обслуговування повітряного руху, оператор аеронавігаційної системи.

\section{Постановки проблеми}

Науково-технічний прогрес значно сприяв підвищенню технічної складової авіаційнотранспортної системи, наприклад, авіаційної техніки до 10-15 разів.

Аналіз стану безпеки польотів, численні дослідження дозволяють стверджувати, що хоча в поточний час рівень безпеки польотів значно вище, ніж десятиліття тому, роль людського фактора в поліергатичній системі майже не зменшилася.

Серед факторів, що домінують, $є$ фактор професійного рівня, пов'язаний з підготовкою авіаційних операторів, у тому числі спеціалістів обслуговування повітряного руху (ОПР).

Комплексний фактор, який поєднує рівень професійної підготовки, психофізіологічний стан, умови праці є причиною 60-80 \% всіх передумов до авіаційних подій.

Незважаючи на зниження відносного ризику в цивільній авіації за кожні 10-15 pp. майже в два рази, частка ризику, що викликана помилками людини, практично залишається на постійному рівні. Уже протягом десятиліть це питання обговорюється в цивільної авіації. Можна припустити, що допоки кінцевою ланкою прийняття рішень у процесі польоту й ОПР залишається людина, ця тенденція не зміниться.
Мета роботи - дослідження проблеми професійної діяльності операторів аеронавігаційної системи та забезпечення надійності функціонування персоналу системи ОПР.

\section{Роль оператора в системі} обслуговування повітряного руху

У 1994 р. в Додатку 1 ICAО було зроблено доповнення, в якому обумовлена вимога до відповідного рівня диспетчерів управління повітряним рухом (УПР) знань з урахуванням їх можливостей [1].

Із цього моменту людський фактор при ОПР отримав офіційний статус.

У загальних вимогах EUROCONTROL щодо змісту початкової підготовки диспетчерів УПР та в навчальному плані стосовно початкової підготовки дисципліна «Людський фактор» є обов' язковою [2].

За ряд десятиліть у системі ОПР в технічному, функціональному, технологічному плані відбулися величезні зміни, але авіадиспетчер все ще виконує і в доступному для огляду майбутньому буде виконувати свою головну функцію: забезпечувати безпечне, упорядковане та економічно вигідне ОПР.

Міжнародною федерацією асоціацій авіадиспетчерів (IFATCA) ця проблема розглядається стільки, скільки вона є федерацією [3]. 
Збільшення показників надійності hardware розвивається на фоні незмінних психофізіологічних можливостей окремо взятої людини-оператора. Основою майже всіх процесів у системі ОПР є наявність серед інших такого центрального елемента, як авіадиспетчер.

Фундаментальні завдання щодо ОПР, роль, відповідальність та методи роботи авіадиспетчерів на фоні величезних перетворень технічної частини аеронавігаційної системи, технічних характеристик повітряних суден (ПС), інтенсивності не змінилися за 30 pp. [4]. Кінцева ефективність системи ОПР буде оцінюватися за ефективністю роботи авіадиспетчера, однією зі складових якої є безпомилкове та своєчасно виконання завдань ОПР.

Безпосередня діяльність авіадиспетчера складається з усунення відхилень у повітряній обстановці від «нормальної» схеми роботи, тобто виконання послідовних дій щодо регулювання елементів об'єкта управління (ПС) та оцінці змін в стані об' єкта.

Послідовність дій, спрямованих на зміну стану об' єкта, для повернення його до «нормальної» схеми відповідно до заявлених та затверджених планів польоту можна описати як алгоритм розв'язку оперативного завдання [5].

Процес професійної підготовки авіадиспетчера складається з засвоєння загального широкого спектра алгоритмів управління об'єктом при різних видах відхилень стану динамічної повітряної обстановки. Це означає, що хоча оператор володіє значним набором алгоритмів, кількісні значення керуючих дій, порядок застосування та комбінування алгоритмів буде різним з урахуванням поточного стану системи, в якій він здійснює управління.

За характером відношення алгоритму, застосованого оператором для усунення відхилень від «нормальної» схеми до алгоритму, що зберігається в довгостроковій пам'яті, оперативні завдання поділяються на шість типів складності.
До нульового типу складності належать завдання, для вирішення яких оператор може застосувати конкретний одиночний алгоритм, що зберігається у нього в довгостроковій пам'яті. Наприклад, для отримання розширеної інформації з формуляру супроводу ПС на панелі управління автоматизованої системи УПР необхідно натиснути відповідну клавішу.

До I типу складності відносяться завдання, для вирішення яких оператор може застосовувати лише узагальнений алгоритм, що зберігається у нього в пам'яті. При цьому він повинен вибрати алгоритм із довгострокової пам'яті, оцінити стан об'єкта управління, тенденції щодо зміні його стану а потім конкретизувати загальний алгоритм у вигляді послідовності конкретних команд управління, визначивши числові значення команд. Наприклад, у процесі здійснення послідовного заходження двох ПС на посадку, борт, що виконує політ позаду, починає «доганяти» перше ПС. Диспетчер оцінює стан (ПС прямує за іншим), тенденції щодо змін (борт, що прямує позаду, починає зменшувати повздовжній інтервал), конкретизує загальний алгоритм у вигляді послідовності конкретних команд управління, визначивши числові значення команд. Узнавши поступову швидкість обох ПС, диспетчер визначає, наскільки потрібно зменшити швидкість для ПС, що прямує позаду, з урахуванням льотно-технічних характеристик, видає управляючи команди 3 конкретним числовим значенням. Наприклад:

KLM 135 ви другий на посадку. Для забезпечення повздовжнього інтервалу швидкість польоту 150 вузлів не більше.

До II та III типів складності належать завдання, які не мають однозначного вирішення, тобто такі, що можуть бути вирішені декількома способами. При вирішенні таких завдань перед оператором додатково постають питання вибору та оптимізації управлінського рішення.

Оперативні завдання II типу складності характеризуються тем, що для їх вирішення в довгострокові пам'яті оператора 
сформовано набір конкретних алгоритмів, які розрізняються за критерієм економічної ефективності. Залежно від ситуації в повітряному русі переважним може бути той чи інший. Наприклад, ПС прямує на ешелоні польоту FL 330. Інше ПС теж бажає зайняти цей рівень, але повздовжній інтервал між ними недостатній. Відомо, що за інших рівних умов ПС, яке вже прямує на цьому ешелоні польоту, має перевагу й може бути залишено на ньому - перший алгоритм. Але це ПС через декілька десятків кілометрів (через 5-7 хв) почне зніжуватися для заходження на посадку, в той час, як інше ПС буде на цьому ешелоні польоту прямувати 500 км. Таким чином, більш економічно вигіднішім буде зниження першого ПС та надання другому ПС дозволу на заняття FL 330 - другий алгоритм.

Вирішення завдань III типу складності базується на застосуванні набору узагальнених алгоритмів. Оператору необхідно вибрати загальний напрям вирішення завдання, конкретизувати його у вигляді послідовності керуючих дій, визначивши числові значення команд. Однак на відміну від завдань попередніх типів складність вирішення завдань III типу та інших більш високих типів обумовлена необхідністю постійної корекції алгоритму розв'язку. Оцінюючи характер змін у ПС та в динамічній повітряній обстановці під впливом команд, авіадиспетчер не тільки уточнює їх числові значення, але й вносить корективи в сам алгоритм розв'язку. Узагальнені алгоритми розрізняються між собою за декілька конкуруючими критеріями безпеки, економічності, швидкості реалізації розв'язку.

Завдання III - IV типів складності виникають при аварійних відхиленнях від «нормальної» схеми.

Приклади алгоритмів цих завдань наведені в керівництві EUROCONTROL щодо підготовки авіадиспетчерів до діяльності в аварійних та нестандартних умовах [6].
Залежно від ситуації, варіанти передбачуваних дій різні, але незмінним залишається алгоритм допомоги ASSIST (див. таблицю).

Алгоритм допомоги в завданнях III - IV типу складності

\begin{tabular}{|l|l|}
\hline $\begin{array}{l}\text { A } \\
\text { (Acknowledge) }\end{array}$ & $\begin{array}{l}\text { Визначити характер аварійної } \\
\text { ситуації та підтвердити } \\
\text { екіпажу прийом аварійної } \\
\text { інформації }\end{array}$ \\
\hline $\mathbf{S}$ (Separate) & $\begin{array}{l}\text { Пам'ятати про необхідність } \\
\text { забезпечення/дотримання } \\
\text { встановлених мінімумів } \\
\text { ешелонування }\end{array}$ \\
\hline $\mathbf{S}$ (Silence) & $\begin{array}{l}\text { У разі необхідності ввести } \\
\text { режим радіомовчання на } \\
\text { робочій частоті }\end{array}$ \\
\hline I (Inform) & $\begin{array}{l}\text { Проінформувати керівника } \\
\text { польотів та суміжні органи } \\
\text { ОПР (сектори) }\end{array}$ \\
\hline $\mathbf{S}$ (Support) & $\begin{array}{l}\text { Надавати максимум допомоги } \\
\text { пілоту та екіпажу. } \\
\text { За можливістю виконувати } \\
\text { всі запити }\end{array}$ \\
\hline $\mathbf{T}$ (Time) & $\begin{array}{l}\text { Надавати пілотам достатньо } \\
\text { часу для вирішення їхніх } \\
\text { проблем. } \\
\text { Не квапити екіпаж з } \\
\text { прийнятяям рішення }\end{array}$ \\
\hline
\end{tabular}

До IV типу складності відносяться завдання, для рішення яких оператор повинен самостійно виробляти алгоритм дії. Це нові завдання й у довгостроковій пам'яті оператора немає алгоритмів їх розв' язку, тобто він не може оператися на інформацію зі своєї довгострокової пам'яті. У цьому випадку він змушений синтезувати розв'язки 3 набору алгоритмів та багажу отриманих знань, залучаючи до цього творчий підхід.

До найбільш складного V типу відносяться завдання, для вирішення яких оператор виробляє послідовність команд, яка суперечить тій, що зберігається у нього в довгострокові пам'яті. Тобто для виконання завдання авіадиспетчер цілеспрямовано іде на порушення керівних документів. 
Від оператора вимагається дуже точна оцінка подій, щоб бути впевненим, що в цій ситуації прийняте ним рішення є єдино можливим.

Позитивне закінчення ситуації $є$ основою для застосування алгоритму подібних дії в майбутньому.

Отже, тенденції розвитку авіаційнотранспортної системи свідчать, що підвищення їі надійності можливе тільки на основі комплексного підходу до організації ОПР.

Основними елементами в цьому процесі $\epsilon$ системи управління якістю, ризиками та людським фактором.

Система управління ризиками повинна створювати таки технологічні процедури, які зможуть надійно забезпечити процеси ОПР.

Система управління якістю повинна перевести ці процедури в правила ОПР та контролювати їх суворе дотримання. Для того, щоб ці процедури та правила виконувалися безпосередніми виконавцями, необхідна система управління людським фактором.

\section{Висновки}

Проаналізовано положення 3 Аеронавігаційної конференції в Монреалі (Канада), 22.09 - 03.10. 2003 р., на якій відповідно до стратегічного плану дії EUROCONTROL щодо підвищення безпеки польотів в рамках Європейської системи організації повітряного руху, до якої відноситься й Україна, у аспектах людського фактору було заявлено:

- постачальники аеронавігаційного обслуговування повинні активізувати свої зусилля та збільшити капіталовкладення для зменшення та ліквідації нехватки авіадиспетчерів;

- усі сторони, що беруть участь (державичлені ICAO), повинні виділити достатню кількість людських ресурсів для регулювання та забезпечення безпеки польотів;

- національні органи з регулювання безпеки польотів під час організації повітряного руху та постачальники аеронавігаційних послуг повинні виділити достатній контингент спеціалістів для підготовки всього експлуатаційного персоналу з питань безпеки польотів як першочергового завдання;

- національні органи з регулювання безпеки польотів під час організації повітряного руху та постачальники аеронавігаційних послуг повинні забезпечити обізнаність авіадиспетчерів у питаннях безпеки, прищепити відповідну культуру та добитися відповідного відношення до цієї проблеми шляхом регулярного відпрацювання дії в аварійних випадках, перепідготовки, проведення курсів підвищення кваліфікації та оптимізації роботи колективу (TRM - Team Resource Management) відповідно до нормативних вимог EUROCONTROL з безпеки польотів;

- постачальники аеронавігаційного обслуговування повинні впровадити управління факторами стресу в критичних ситуаціях як невід' ємного елементу системи забезпечення безпеки

\section{Література}

1. Bыдача свидетельств авиационному персоналу. Приложение 1 к Конвенции о международной гражданской авиации. - Монреаль: ИКАО, 2006. - 110 с.

2. Guidelines for ATCO Common Core Content Initial Training. - B.: Eurocontrol, 2004. - 104 p.

3. Черчилл Дуглас. Центральный элемент в системе / Дуглас Черчилл // Новости аэронавигации. - 2002. - №3, июнь. - С. 10-11.

4. First ATC Support Tools Implementation (FASTI) programme. - Eurocontrol, 2006. $39 \mathrm{p}$.

5. Галактионов А. И. Психологические факторы операторской деятельности / А.И. Галактионов, В. Ф. Венда, В. А. Вавилов. - М.: Наука, 1988. - 200 с.

6. Guidelines for Controller Training in the Handling of Unusual/Emergency Situations. B.: Eurocontrol, 2003. - 50 p. 